\title{
ANALISIS KESULITAN DALAM MEMAHAMI KEMAMPUAN VERBAL DALAM MEMBUAT MODEL MATEMATIKA PROGRAM LINEAR
}

\author{
Mahsup \\ Program Studi Pendidikan Matematika Universitas Muhammadiyah Mataram \\ supyeka@gmail.com
}

\section{INFO ARTIKEL}

Riwayat Artikel:

Diterima:25-05-2018

Disetujui:28-07-2018

\section{Kata Kunci:}

Kesulitan Belajar Kemampuan Verbal

Kemampuan Numerik

\section{ABSTRAK}

\begin{abstract}
Abstrak:: Penelitian ini bertujuan untuk mengetahui Faktor-faktor yang mempengaruhi kesulitan mahasiswa dalam memahami kemampuan verbal pada materi Program Linear mahasiswa semester IV Prodi Pendidikan Matematika FKIP UM Mataram. Penelitian ini menggunakan metode deskriptif kualitatif. Dalam penelitian ini subjek penelitian sebanyak 4 mahasiswa yang ditentukan berdasarkan hasil tes kemampuan numerik Program Linear. Data dikumpulkan dengan metode tes. Tes soal digunakan untuk menganalisis kesulitan mahasiswa dalam menyelesaikan soal Program Linear. Metode analisis yang digunakan adalah analisis deskriptif kualitatif. Berdasarkan hasil tes dan analisis jawaban mahasiswa adapun faktor-faktor yang mempengaruhi kesulitan mahasiswa dalam kemampuan verbal adalah mahasiswa kurang mampu membuat model matematika program linear, menguji titik-titik kritis dan menentukan nilai maksismum atau minimum.
\end{abstract}

\section{A. LATAR BELAKANG}

Pendidikan dalam arti luas telah mulai dilaksanakan sejak manusia berada dimuka bumi ini. Adanya pendidikan adalah setua dengan adanya kehidupan manusia itu sendiri (Dwi Siswoyo,dkk, 2007:16). Oleh karena itu pendidikan merupakan salah satu unsur penting yang mempengaruhi kelangsungan hidup manusia, baik secara langsung maupun tidak langsung. Telah tersirat dalam tujuan pendidikan nasional berdasarkan UU 20 tahun 2003 pasal 3 yaitu: pendidikan nasional berfungsi mengembangkan kemampuan dan membentuk watak serta peradaban bangsa yang bermanfaat dalam rangka mencerdaskan kehidupan bangsa, bertujuan untuk berkembangnya peserta didik agar menjadi manusia yang beriman dan bertakwa kepada Tuhan Yang Maha Esa, berahlak mulia, sehat, berilmu, cakap, kreatif, mandiri, dan menjadi warga negara yang demokrasi serta bertanggung jawab. Dalam hal ini pemerintah mengharapkan dengan adanya pendidikan, masyarakat atau peserta didik dapat mempersiapkan dirinya untuk menjadi manusia yang memiliki ahlak mulia, memiliki pengetahuan serta dapat melaksanakan tugas dan tanggung jawab baik secara hidup bermasyarakat.

Matematika adalah ilmu pengetahuan yang dipelajari sejak zaman dahulu hingga kini. Mata pelajaran wajib di sekolah dalam tingkatan apapun. Hal ini di karenakan matematika mendasari perkembangan ilmu pengetahuan dan teknologi modern yang terjadi di dunia. Tujuan pembelajaran matematika di Indonesia termuat dalam Permendiknas Nomor 22 Tahun 2006. Permendiknas tersebut tertulis mata pelajaran matematika tingkat SMP bertujuan agar peserta didik memiliki kemampuan sebagai berikut:

1. Memahami konsep matematika, menjelaskan keterkaitan anatar konsep dan mangaplikasikan konsep atau algoritma, secara luas, akurat, efisien, dan tepat, dalam pemecahan masalah.

2. Menggunakan penalaran pada pola dan sifat melakukan manipulasi matematika dalam membuat generalisasi, menyusun bukti, atau menjelaskan gagasan dan pernyataan matematika.

3. Memecahkan masalah yang meliputi kemampuan memahami masalah, merancang model matematika, menyelesaikan model dan menafsirkan solusi yang di peroleh.

4. Mengkomunikasikan gagasan dengan simbol, tabel, diagram atau media lain untuk memperjelas keadaan atau masalah.

Dalam proses belajar mengajar terjadi komunikasi antara dosen dan mahasiswa atau mahasiswa dengan mahasiswa. Dalam berkomunikasi dosen harus bisa memberikan penjelasan tentang materi pelajaran yaitu dengan menggunakan bahasa yang dapat dimengerti oleh mahasiswa. Jika bahasa yang digunakan dalam menjelaskan materi tidak dipahami oleh mahasiswa, maka akan menimbulkan 
kesulitan bagi mahasiswa dalam menguasai materi pelajaran tersebut. Materi Program Linear banyak disajikan dalam bentuk cerita. Kemampuan verbal yang memadai sangat di perlukan dalam menyelesaikan soalsoal matematika dalam bentuk cerita, karena dalam kemampuan verbal maka mahasiswa akan lebih mudah dalam mengartikan maksud soal.

Senada dengan pernyataan Sukardi (1997:115) mengemukakan bahwa kemampuan verbal adalah kemampuan memahami ide-ide yang di ekspresikan dalam bentuk kata-kata. Jadi kemampuan verbal yang dimaksud dalam penelitian ini adalah kemampuan mengartikan kata-kata atau kalimat dalam soal. Selain itu, untuk menguasai materi Program Linear mahasiswa harus memiliki kemampuan dalam mengoperasikan bilangan secara manual dengan operasi hitung biasa seperti operasi perkalian dan pembagian, sehingga kemampuan numerik juga diperlukan dalam menyelesaikan soal-soal matematika khususnya materi Program Linear.

Berdasarkan hasil pengamatan sebagai dosen pada semester IV tahun ajaran 2015/2016 di prodi Pendididkan diketahui bahwa materi Program Linear merupakan materi yang dianggap sulit oleh mahasiswa terutama untuk soal cerita. Hal ini terlihat dari nilai rata-rata UTS dan UAS pada materi Program Linear pada kategori rendah yaitu mahasiswa hanya memperoleh rata-rata nilai 56 . Selain itu, sebagian besar mahasiswa masih kurang mampu menterjemahkan soal-soal yang berbentuk cerita ke dalam simbol matematika. Jadi diduga bahwa kemampuan verbal mahasiswa masih kurang memadai. Seorang mahasiswa yang kemampuan verbalnya kurang akan mengalami kesulitan dalam memahami dan menterjemahkan maksud soal ke dalam simbol matematika dan akhirnya mahasiswa tidak mampu menyelesaikan soal tersebut. Akibatnya penguasaan matematika mahasiswa akan menjadi rendah.

Dalam proses belajar mengajar dosen sangat diperlukan untuk mengatasi kesulitan menyelesaikan soal-soal Program Linear. Oleh karena itu seorang dosen perlu mengetahui kesulitan mahasiswa dalam menyelesaikan soal-soal matematika. Penelitian ini akan menggali faktor-faktor apa saja yang menyebabkan mahasiswa mengalami kesulitan dalam materi Program Linear. Dengan demikian diharapkan dosen dapat mengambil atau menentukan usaha yang tepat untuk mengatasi masalah tersebut demi perbaikan dalam pembelajaran matematika.

Tujuan penelitian yang hendak dicapai dalam penelitian ini yaitu untuk mengetahui faktor-faktor yang mempengaruhi kesulitan mahasiswa dalam memahami kemampuan verbal terhadap materi Program Linear.

\section{B. METODE PENELITIAN}

\section{Rancangan Penelitian}

Metode yang digunakan dalam penelitian ini adalah penelitian kualitatif. Dalam penelitian ini, tidak ada hipotesis. Data yang dihasilkan adalah data deskriptif yang berupa kata-kata tertulis atau lisan. Strategi penelitian yang digunakan adalah metode deskriptif kualitatif. Penelitian deskriptif adalah penelitian yang memberikan gambaran dari suatu gejala yang ada dan menjawab pertanyaan-pertanyaan yang ada yang berhubungan dengan status (keadaan) subyek penelitian pada saat tertentu.

\section{Waktu penelitian}

Penelitian ini dilaksanakan pada bulan Maret sampai dengan bulan April.

\section{Jenis dan Sumber Data}

Jenis data yang digunakan dalam penelitian ini adalah tes, dan lembar observasi. Sumber data dalam penelitian ini yaitu berupa tes soal. Tes soal merupakan tes yang dirancang untuk keperluan mendiagnosis kesulitan-kesulitan yang dilakukan mahasiswa dalam menyelesaikan persoalan Program Linear.

\section{Instrumen Penelitian}

Instrumen penelitian yang digunakan dalam penelitian ini adalah Tes Program Linear, merupakan tes yang dirancang untuk keperluan mendiagnosis kesulitan-kesulitan mahasiswa terhadap kemampuan verbal dalam menyelesaikan soal Program Linear. Berdasarkan hasil tes tersebut dapat diidentifikasi kesulitan mahasiswa berupa kesalahan-kesalahan mahasiswa dalam menjawab soal yang berkaitan dengan materi perkuliahan.

\section{Teknik Penggumpulan Data}

Data yang diharapkan berupa hasil pekerjaan mahasiswa pada lembar jawab yang disertai dengan langkah-langkahnya. Tujuan diadakannya tes ini adalah untuk mengetahui sampai di mana kemampuan verbal mahasiswa dalam menyelesaikan soal Program Linear. Data hasil tes ini digunakan sebagai dasar menentukan subjek penelitian dan bahan pengamatan mengenai kesalahan mahasiswa dalam menyelesaikan soal Program Linear. Hasil pengerjaan mahasiswa yang telah ditetapkan sebagai subjek penelitian diberi skor dengan ketentuan jika mahasiswa salah dalam menuliskan suatu langkah yang berkaitan dengan konsep dan prinsip diberi skor o dan jika mahasiswa benar dalam menuliskannya diberi sesuai dengan bobot (penskoran) soal yang telah ditentukan.

Kumpulan data berupa skor dianalisis untuk mengetahui persentase tingkat kesulitan mahasiswa pada penguasaan knnsen dan prinsip. Pengerjaan mahasiswa yang l dianalisis kemudian dikelompokkan kedalam jenis-jenis kesalahan yang berkaitan dengan konsep dan prinsip.

\section{Analisis Data}

Data yang diperoleh dalam penelitian ini berupa data hasil tes, dan hasil observasi. Setelah data terkumpul dilakukan reduksi data yang bertujuan untuk memfokuskan pada hal-hal yang akan diteliti yaitu menganalisis jawaban mahasiswa yang telah dipilih sebagai subjek penelitian. Analisis data dilakukan secara deskriptif analitik, dengan kriteria:

Apabila mahasiswa membuat kesalahan yang berkaitan dengan konsep dari setiap langkah dalam menyelesaikan soal, maka mahasiswa 
tersebut dinyatakan mengalami kesulitan dalam memahami konsep.

Apabila mahasiswa membuat kesalahan yang berkaitan dengan prinsip dari setiap langkah dalam menyelesaikan soal, maka mahasiswa tersebut dinyatakan mengalami kesulitan dalam memahami prinsip.

Dalam penelitian ini digunakan teknik analisis data deskriptif kualitatif dengan reduksi data. Reduksi data adalah suatu bentuk analisis yang menajamkan, menggolongkan, mengarahkan, membuang data yang tidak perlu, dan mengorganisasi data dengan cara sedemikian rupa sehingga kesimpulan finalnya dapat ditarik dan diverifikasi.

Tahap reduksi data dalam penelitian ini adalah mengoreksi hasil pekerjaan mahasiswa dengan cara penskoran, yang akan digunakan untuk menentukan subjek penelitian.

Penyajian data adalah sekumpulan informasi tersusun yang memberi kemungkinan penarikan kesimpulan dan pengambilan tindakan. Dalam tahap ini data yang berupa hasil pekerjaan mahasiswa disusun menurut urutan objek penelitian.

Tahap penyajian data dalam penelitian ini meliputi: Menyajikan hasil pekerjaan mahasiswa yang telah dipilih sebagai subjek penelitian.

\section{HASIL DAN PEMBAHASAN}

\section{Deskripsi Hasil Penelitian}

Tes dilaksanakan pada hari jum'at tanggal 4 Agustus 2016 pada mahasiswa semester IV program studi Pendidikan Matematika FKIP UM Mataram. Dimana jumlah mahasiswa sebanyak 4 orang, namun ada 1 orang yang tidak hadir pada saat ujian dikelas.

Tes diberikan kepada mahasiswa setelah mengajarkan materi Program Linear yang berkaitan dengan cara menganasis dan membuat model matematika dari masalah yang berkaitan dengan program linear. Berdasarkan hasil pekerjaan peserta didik dalam mengerjakan soal-soal pada materi Program Linear, ditemukan beberapa kesalahan menyangkup pada kemampuan verbal yang dilakukan oleh mahasiswa. Kesalahan-kesalahan tersebut akan disajikan sebagai berikut.

Soal Tes : Seorang pedagang khusus menjual produk A dan produk B. produk A dibeli seharga Rp.2.000.0oo per unit dan dijual dengan laba Rp.800.00o per unit. Produk B dibeli seharga Rp.4.000.000 per unit dan dijual dengan laba Rp.600.000. jika ia mempunyai modal Rp.1.600.00o dan gudangnya mampu menampung paling banyak 500 unit, maka keuntungan terbesar diperoleh bila ia membeli...

Dari jawaban mahasiswa kemudian dianalisis untuk mengetahui kemampuan verbal mahasiswa dalam menjawab soal diatas. Dari jawaban ketiga mahasiswa tersebut dapat dianalisis kemampuan verbalnya dalam memahami dan menyelesaikan masalah soal program linear sebagai berikut:
1. Mahasiswa belum dapat memahami variable keputusan dari masalah yang berkaitan dengan yang disajikan diatas

2. Mahasiswa tidak bisa membuat fungsi tujuan. Dimana fungsi tujuan sebagai kombinasi linear dari variable keputusan

3. Selain itu mahasiswa juga tidak bisa menentukan variable pembatas atau syaratsyarat.

4. Mahasiswa tidak bisa memformulasi atau membuat model matematika dari persoalan tersebut.

5. Mahasiswa tidak bisa menentukan solusi dengan menggunakan metode grafik

Soal tes : Diketahui maksimum $\mathrm{z}=20 \mathrm{x}+8 \mathrm{y}$

dengan syarat $\mathrm{x}+\mathrm{y} \leq 20,2 \mathrm{x}+\mathrm{y} \leq 46, \mathrm{x}, \mathrm{y} \geq 0$.

Tentukan nilai maksimum dari persoalan program linear tersebut.

Berdasarkan jawaban dari mahasiswa, dapat dianalisis hasil jawabanya sebagai berikut :

1. Semua mahasiswa bisa membuat grafik dan menentukan daerah penyelsaiannya

2. Dari 3 orang mahasiswa ada 1 orang yang tidak bisa melakukan proses eliminasi dan substitusi terhadap 2 garis yang saling berpotongan.

3. Mahasiswa belum dapat menentukan titik kritis dari daerah penyelesaian yang telah ditentukan.

4. Semua mahasiswa tidak dapat menemukan nilai maksimum, peroses jawaban mahasiswa sampai eliminasi dan substitusi.

\section{Pembahasan}

Hasil analisis data berdasarkan tes kemampuan verbal yang dilakukan menunjukkan, bahwa peserta didik mengalami kesulitan dalam menyelesaikan persoalan materi Program Linear yang diberikan. Kesulitan mahasiswa pada umumnya berupa kesulitan tentang menentukan membuat model matematika program linear, menguji titik-titik kritis dan menentukan nilai maksismum atau minimum. Kesulitan mahsiswa tentang hal tersebut mengakibatkan mahasiswa menggunakan prosedur penyelesaian soal yang tidak benar.

\section{SIMPULAN DAN SARAN}

\section{Kesimpulan}

Berdasarkan hasil tes dan analisis jawaban mahasiswa adapun faktor-faktor yang mempengaruhi kesulitan mahasiswa dalam kemampuan verbal adalah mahasiswa kurang mampu membuat model matematika program linear, menguji titik-titik kritis dan menentukan nilai maksismum atau minimum.

\section{Saran}

Peneliti berharap hasil penelitian ini dapat memberikan masukan pemikiran demi meningkatkan mutu pendidikan, khususnya dalam pengajaran matematika diprodi Matematika UM Mataram. Untuk itu peneliti berusaha memberikan beberapa saran antara lain:

1. Bagi dosen 
a. Dosen dalam membentuk pola pengajaran matematika hendaknya tidak semata-mata ditujukan pada keterampilan peserta didik dalam menyelesaikan soal. Namun yang lebih penting adalah bagaimana caranya mengajak peserta didik untuk memahami dan mengerti serta menguasai materi-materi yang ada secara baik dan benar, sehingga peserta didik tidak mengalami kesulitan dalam menyelesaikan soal-soal pada materi Program Linear.

b. Dosen diharapkan menggunakan strategi atau metode mengajar yang lebih kreatif guna meningkatkan kemampuan verbal dan numerik.

c. Dosen diharapkan selalu memberikan motivasi belajar kepada peserta didik agar peserta didik mempunyai perhatian dan minat dalam belajar matematika pada pokok bahasan Program Linear.

2. Bagi peneliti lain

Meneliti strategi mengajar yang cocok untuk meningkatkan kemampuan verbal.

\section{DAFTAR PUSTAKA}

[1] Budiarto dkk, 2004. Materi Pelatihan Terintegrasi Matematika. Jakarta: Depdiknas.

[2] Hasan, 1994. Dimensi-dimensi Psikologi Pendidikan. Surabaya: Usaha Nasional .

[3] Hendyat Sutopo, 1987. Keunikan Intelegensi Manusia.Surabaya: Usaha Nasional.

[4] Hudoyo, H, 1979. Pengembangan Kurikulum Matematika dan Pelaksanaannya di depan Kelas. Surabaya: Usaha Nasional.

[5] Ibrahim, 1996. Perencanaan Pengajaran. Jakarta: Rineka Cipta

[6] Manullang, M, 2003. Pengaruh Penguasaan Numerik dan Penguasaan Verbal terhadap Prestasi Belajar Matematika. Jurnal Ilmu Pendidikan Vol 10 No 2, Juni 2003, FMIPA UNIMED, Medan.

[7] Mulyono, 1999. Pendidikan Bagi Anak Berkesulitan Belajar. Jakarta: Rineka Cipta

[8] Polya, G. 1973, How To Solve It. New Jersey: Princeton University Press.

[9] Reni Akbar, Wihardjo, Wiyono, 2001. Keberbakatan Intelektual. Jakarta: Gramedia Widi Sarana.

[10]Sardiman, A, 2001. Interaksi dan Motivasi Belajar Mengajar. Jakarta: Grafindo Persada.

[11] Slameto, 2003. Belajar dan Faktor-faktor yang Mempengaruhinya. Jakarta: Rineka Cipta

[12]Sukardi, 1997. Analisis Tes Psikologis. Bandung : Rineka Cipta

[13]Suparno, 1997. Filsafat Knstruktivisme dalam Pendidikan. Yogyakarta: Kanisius.

[14]Sugiyono, 2013. Metode Penelitian Kuantitatif, Kualitatif dan RD. Bandung: $\quad$ ALFABETA.

[15] Winkel, W.S, 1996. Psikologi pengajaran. Jakarta: PT Gramedia. 